
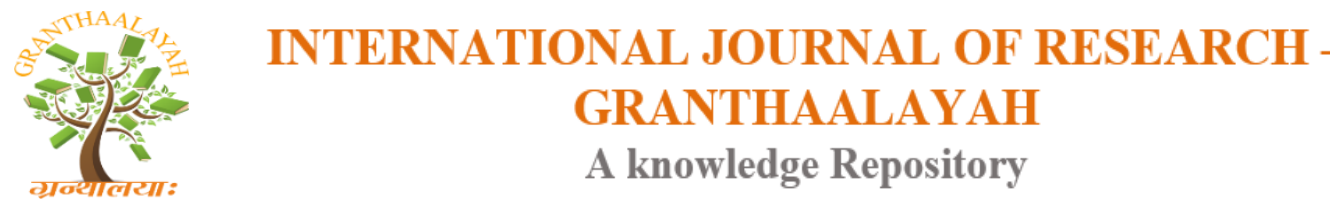

Science

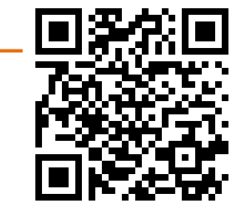

\title{
COMMERCIALIZATION OF CARBON CREDITS ON SMALL PROPERTIES
}

\author{
Jadson Belem de Moura *1, Rodrigo Fernandes de Souza ${ }^{1}$, José Mateus dos Santos ${ }^{1}$, Luiz \\ Cesar Lopes Filho ${ }^{2}$, Willian Marques Pires ${ }^{3}$, Walber Alves Ribeiro ${ }^{4}$ \\ ${ }^{*}$ Evangelical Faculty of Goianésia, Sedmo - Soils, Ecology and Dynamics of Organic Matter, \\ Brazil. \\ 2 Universidade Federal de Goiás - Programa de Pós-Graduação em Fitossanidade. Instituto de \\ Ensino Superior de Rio Verde. \\ ${ }^{3}$ Instituto Federal Goiano, Campus Rio Verde - Programa de Pós-Graduação em Agronomia \\ ${ }^{4}$ Universidade Estadual Paulista "Júlio de Mesquita Filho" - Campus Jaboticabal
}

\begin{abstract}
Today the world has turned its attention to the phenomena of climate change on the planet. Excess emissions of greenhouse gases (GHG) from human activity are responsible for this change. Gases such as carbon dioxide (CO2), methane $(\mathrm{CH} 4)$ and nitrous oxide $(\mathrm{N} 2 \mathrm{O})$ are part of $\mathrm{GHG}$ and have a large capacity to store the energy of the sun in the form of heat, increasing the average temperature in the atmosphere. After the Kyoto treaty, major powers pledged to reduce GHG emissions into the atmosphere, but this practice implies a slowdown in the industrialization and profits of these countries. Countries that can not or do not opt to reduce emissions can buy credits from nations that can generate extra emission reduction values, thus resulting in trade in these credits. Small properties have the potential for credit production, which can generate extra income for the small producer. Therefore, this work aimed at evaluating the potential of commercialization of carbon credits by small properties. The methodology of the work consisted in a systematic literature review on the current state of the art of the proposed theme.
\end{abstract}

Keywords: Carbon Not Soil; Family Farming; Small Producers; Agroecology.

Cite This Article: Jadson Belem de Moura, Rodrigo Fernandes de Souza, José Mateus dos Santos, Luiz Cesar Lopes Filho, Willian Marques Pires, and Walber Alves Ribeiro. (2019). "COMMERCIALIZATION OF CARBON CREDITS ON SMALL PROPERTIES." International Journal of Research - Granthaalayah, 7(7), 156-166.

\section{Introduction}

Today the world has turned its attention to the phenomena of climate change on the planet. The excess emissions of greenhouse gases (GHG) caused by human activity are responsible for this change (CARVALHO et al., 2010). 
Gases such as carbon dioxide (CO2), methane (CH4) and nitrous oxide (N2O) are part of GHG and have great capacity to store the energy of the sun as heat, increasing the average temperature in the atmosphere (CONEJERO, 2006) .

The change in temperature dynamics negatively affects life on earth at several points. From the rainfall regime and food production to the maintenance of species of animals adapted to all types of climates (CARVALHO et al., 2010).

The accumulation of GHG causes the increase of the average temperature of the atmosphere. The increase of this temperature accelerates the GHG emission processes, further increasing its concentration in the atmosphere, thus initiating a destructive and dangerous cycle (MACIEL et al., 2009). However, there is a way to reverse this cycle. Productive management practices that seek to accumulate carbon in the plant structure, thus avoiding the emission of excess carbon, such practice is called carbon sequestration (YU, 2004).

In 1997 in Kyoto, concerned about the increase of GHGs in the atmosphere and the greenhouse effect, the United Nations (UN) established a series of rules intended to control this emission in order to mitigate the evils of the effect (Gomes et al., 2009). A series of targets were set for all participating countries to be achieved, known as the Kyoto Protocol. Nations that may, by chance, achieve their goals reliably, could transfer the excess to nations that failed or did not want to reach the goal.

This has led to the practice where nations that can meet their emissions targets generate extra credits that can be traded with nations that can not reach them.

Any practices that prevent the emission of GHG can generate credits that can be commercialized. Brazil, with environmental policies such as the use of renewable fuels, conservation planting systems and organic agriculture has been shown to be a power in the generation of tradable carbon credits (CARVALHO et al., 2010).

Family farming has great potential in generating carbon credits. By default, it is not extensively present in agricultural production, mostly using low carbon conservation practices (ROQUE RODIGHERI; ROBERTO GRAÇA; APARECIDA DE LIMA, 2005).

Thus, this work aimed to evaluate the potential of commercialization of carbon credits by small properties.

\section{Materials and Methods}

The methodology of the work consisted in a systematic literature review on the current state of the art of the proposed theme. Being developed from a current bibliographical survey of academic scientific works of Brazil and the world. 


\section{Results and Discussions}

\section{Greenhouse Effect}

In recent years, much has been said about global warming, greenhouse gases, and other phenomena caused or potentiated by human activities (TOLENTINO \& ROCHA-FILHO, 1998).

This phenomenon occurs naturally and is of fundamental importance for the existence of life on the planet (YU, 2004). According to Carvalho et al. (2010) Carvalho et al., (2010), the natural greenhouse effect occurs due to concentrations of greenhouse gases (GHG) in the atmosphere before the appearance of man. These gases are responsible for partially retaining solar energy in the atmosphere by raising the average air temperature. And without these gases, which act as a natural blanket around the earth, absorbed solar thermal infrared radiation would dissipate in space and the surface of our planet would be $33^{\circ}$ colder than it is today (YU, 2004).

The problem is the increase in GHG concentration in the atmosphere due to human activities such as the burning of fossil fuels and deforestation, this has caused concern, since these actions can change the basic conditions for life on the planet (FERNANDES et al. 2007).

The gases responsible for the effect are: Carbon Dioxide, Methane, Nitrous Oxide, Sulfur Hexafluoride, Ozone, Chlorofluorocarbons (CFCs), Hydrochlorofluorocarbons (HCFCs) (TOLENTINO; ROCHA-FILHO, 1998).

Among GHGs, carbon dioxide (CO2) is primarily responsible for intensifying the greenhouse effect and resulting in climate change. Among these changes, it is verified that the average temperature of the planet is increasing. It presents an increasing frequency of instabilities in the pluviometric regime in several regions of the planet, including Brazil (FERNANDES et al., 2007).

GHG emissions have increased linearly since the industrial revolution. It is estimated that about $35 \%$ of anthropogenic emissions are the responsibility of agriculture (FOLEY et al., 2005). All the other gases that make up the GHG have also had their concentrations high since the measurements were started (ALBRECHT; KANDJI, 2003; IPCC, 2014). Thus, the concentration of these GHGs in the atmosphere is increasing and the need for measures to mitigate these emissions is evident.

\section{Carbon Credit}

In 1992, Rio de Janeiro hosted Eco92, the UN convention that initiated the discussion on climate change that was being verified. At the time 185 nations together with the European Union committed themselves to adopt policies to reduce GHG emissions with the aim of stabilizing concentration and control of the greenhouse effect based on two basic principles: precaution and responsibility. Where the precautionary principle was based on the lack of scientific information that GHG was in fact responsible for increasing the average temperature of the atmosphere and the responsibility principle attributed developed nations to the responsibility for most GHG emissions (CONEJERO, 2006).

After a number of studies and negotiations in Kyoto City in 1997, a concrete proposal to reduce GHG emissions was put in place. All participating nations would have 10 years to adapt technologies and policies that would actually reduce GHG emissions. The stipulated limit was the $95 \%$ reduction in GHG emissions emitted in the 1990s. Flexibility mechanisms were also 
stipulated, where nations able to achieve their emissions targets could generate credits and trade with nations that this could not imply in the deceleration of production and the economy (CONEJERO, 2006; FOLEY et al., 2005)

Countries that develop certified activities with GHG emission reductions can generate CERs Certified Emissions Reductions - that are marketable and can be acquired by countries, accounting as part of their savings in GHG emissions (CONEJERO, 2006).

According to Conejero, (2006), there are three ways for one country to transfer the credits produced to another:

- Joint implementation: Countries can develop environmental policies of low GHG emissions together. This opens up an opportunity to invest resources from economically developed countries in practices developed in industrializing countries. In this situation, credits produced by the country that received investments to develop low-emission environmental projects count positively for both countries involved.

- Emissions Trading: The classic case of trading carbon credits, where a country that failed or failed to meet its emission quotas, paid to another country that was able to meet its quotas and generate credits. Such credits may be marketed by the private sector.

- Clean Development Mechanisms: Low-GHG environmental state policies without capital investment from other nations can be converted into credits and marketed to interested nations.

- Failure to meet the targets set by the Kyoto Protocol results in fines of around $€ 40$ per tonne of CO2 emitted (MACIEL et al., 2009). Taking into account that developed countries emitted around 36.3 billion tons of CO2 in 2016 (IPCC, 2014), the value of this fine could seriously affect the economies of these countries

As of 2005, carbon credit began to be traded on the stock exchange, initially regulated by the supply and demand of credits. The European Union pioneered the purchase of credits (MACIEL et al., 2009).

According to the stock market and financial market monitoring website INVESTING.COM (2017), currently the carbon credit is traded at a price of around 5 U \$ S / TCO2. In 2008, carbon credit reached its highest market value reaching 28.77 US \$ / TCO2. Even though it is not valued as in previous years, commercialization of credits may represent an interesting complementary income for institutions, individuals and the state.

\section{Small-Cap Carbon Credits}

Any area with up to 30 hectares exploited by family labor (ABDO; VALERI; MARTINS, 2008) can be considered a small property. Usually income on small farms comes from the production of vegetables that supply the cities through free markets and consumer markets (CAMPANHOLA; VALARINI, 2001).

Small properties have excellent potential for the production and marketing of carbon credits. There is a lack of technical knowledge and instruction on how to explore this alternative income possibility (RODIGHERI; ROBERTO GRAÇA; LIMA, 2005). 
The size of the properties, the amount of credits to be traded and the certification are some of the limitations that small properties may face in order to enter the carbon credits market satisfactorily, however, these limitations can be overcome by adopting the cooperative system. A single property would not be able to afford the certification or even produce sufficient credits to be marketed to the point of covering deployment costs. But producer cooperatives have the strength to do so (PINHO, 1982).

Working in cooperatives can bring strength and added value in products and services developed by the small producer. Cooperatives act by making available to all associates services such as technical advice, certification, more advantageous commercial contracts, support and renting of machines and purchases of inputs, which previously would have been much more difficult for the producer to access (PINHO, 1982; SHNEIDER, 2003)

Carbon credits would come as an alternative source of income to each partner's primary source of income. Recalling that conservationist productive systems, tend to accumulate more carbon credits, in this case, a more profitable alternative. In this perspective, organic systems would be more advantageous, besides having a more aggregated value in their products, they generate higher values of carbon credits that can be commercialized (CAMPANHOLA; VALARINI, 2001; GOMES, 2004; VEIGA, 1996).

Some practices adopted by the farmer in the field can also be accounted for as carbon credits production. In addition to the fact that organic systems generate credits, production in conservation systems such as no-till, agroforestry (saf) system, sustainable integrated agroecological program (country) and agrosilvipastoril system (sasp) can generate even more credits (CARVALHO et al. al., 2010).

Another practice that can generate carbon credit on small property is the conservation of protected areas. The cerrado has some areas that are protected by law, such as springs and slope areas. These areas have much carbon incorporated into the soil that can be counted as carbon credits (WINCK et al., 2014). In this perspective, the environmental tourism exploration can also generate income with carbon credits, as long as they aim at the conservation of the natural resources.

It is also possible to obtain carbon credits from livestock production, a practice that normally contributes to the increase of GHG emissions. If pigs and cattle production is handled in a conventional manner, due to the physiology of these animals, it generates a large quantity of GEE (Barichello et al., 2015).

\section{Cerrado}

The cerrado is the second largest Brazilian biome (after the Amazon) and concentrates no less than a third of the national biodiversity and 5\% of the world's flora and fauna. The Brazilian savannas correspond to more than 200 million hectares distributed in the central-west, north, northeast and southeast regions, and have great natural renewable resources adapted to the rigid climatic, edaphic and water conditions (RATTER, 1997).

The cerrado has a great variation of vegetation physiognomies, ranging from fields with few shrubs to closed forests. (RATTER, 1997), and according to Walter (2006), there is no consensus among 
the authors regarding the classification of cerrado physiognomies, with more than 700 names used in the definitions of this biome, which compromises the understanding of vegetation, practices.

In the last decades, thanks to studies for soil management and the proximity of the consumer centers, the Cerrados now have considerable importance in the country's agricultural production, and it is currently one of the largest grain producing regions in Brazil. The construction of dams, roads, mining, agrochemicals and urban expansion also threaten the integrity of the Cerrado's ecosystems and renewable natural resources (AGUIAR; MONTEIRO, 2005).

According to Lopes (1984), the organic matter of the soil is essential for the conservation of the natural resources present in this biome (ROSCOE; MERCANTE; SLATON, 2006). fertility of cerrado soil.

\section{Carbon in Soil}

According to $\mathrm{Yu},(2004)$, the four major carbon stocks are the atmosphere, oceans, fossil fuel deposits and terrestrial biomass and soil, and carbon sequestration is proportional to plant growth. Thus, the larger its size, the more biomass accumulates, and consequently the more carbon is fixed. Most of the terrestrial carbon is accumulated in the forest soil by the decomposition of organic matter.

Organic matter are remains of living beings, animals or plants, decomposed or decomposing, composed essentially of carbons (YU, 2004).

The accumulated litter equals the difference between the deposition and the decomposition of the vegetative material, of this material deposited on the soil, which process returns the nutrients to the soil (CALDEIRA et al., 2008).

Deforestation and the implantation of agrosystems tend to reduce the carbon content $(\mathrm{C})$ in the soil, mainly due to erosion, and reduced green mass production (CARVALHO et al., 2010).

\section{Agroecological Systems}

In conventional systems of production, there is soil revolving, a practice that accelerates the burning of the carbon stored in the soil releasing as CO2 in the atmosphere (WOHLENBERG et al., 2004). This type of preparation will cause loss of organic matter (C), especially in the range of up to 20cm deep (CASTRO FILHO; MUZILLI; PODANOSCHI, 1998).

Sustainability has as its premise the integration of environmental, social and economic aspects that aim at social justice, quality of life, environmental balance (JACOBI, 2003).

The agro-ecological systems are summarized in the application of concepts and principles of Ecology, Agronomy, Sociology, Anthropology, Communication Science, Ecological Economics and other areas in new management methods, aiming sustainability over time, and the substitution of conventional models for sustainable models (CAPORAL; COSTABEBER, 2002).

Among the agroecological systems with the greatest potential for generating carbon credits, we can mention: 
SASP - Agro Silvo Pastoril System: It consists of the introduction of trees in the pasture, with the objective of increasing the quantity and nutrient availability of the intercropped crops by intercepting the nutrients located in deeper layers of the soil by the roots of the trees, on the surface for fodder. This occurs with the deposition and decomposition of its vegetative material (GYENGE et al., 2002).

PAIS - Integrated and Sustainable Agroecological Production (Mandala System): The COUNTRY consists of a reservoir of water for fish farming or a structure for handling small animals being circulated by flowerbeds in order to make better use of the space, considering that the system is used most often on small properties. Usually, in this system, vegetables and greenhouses are cultivated in general (CAPORAL; COSTABEBER, 2002; SOUZA COSTA et al., 2013).

SAF - Agroforestry System: Consists in the cultivation of fruit trees, native and exotic, of medium to large size, where it is expected a greater production of vegetative material, and consequently a greater cycling of nutrients through the decomposition of the litter (ARATO, MARTINS.

Isolation of springs and riparian forests (APPs) consists of isolating the area to be recovered, with the aim of preventing access of animals to protected areas, and allowing their recovery in a natural way (SANTANA; LIMA; MAGALHÃES, 2004).

\section{Biodigesters in Small Properties}

Brazil is one of the largest animal producers with one of the largest herds of pigs and cattle, and leads the export of the products and by-products of these animals to the whole world (BARICHELLO et al., 2015). However, this extensive production generates a large GHG emission, and only now has the attention to the biodigestion and the use of the gases emitted by these animals as an energy source, and may even have their carbon credits marketed (XAVIER; JÚNIOR, 2010).

GHGs in extensive production systems are derived from the release of digestive tract gases from these animals. For the use of these gases it is necessary to use a biodigester, which is an equipment where the organic matter fermentation takes place in a controlled way, providing the reduction of the environmental impact and the generation of fuel of low cost. With the decomposition of the wastes through the performance of microorganisms, two by-products are generated, biogas, which can be used as energy source, and the biofertilizer, which can be commercialized or even used in the same property in other activities (VIVAN et al. 2010).

Microbial activity, through anaerobic metabolism, generates biogas, composed of a mixture of various gases, among them methane, carbon dioxide, hydrogen and sulfur dioxide. Biogas is flammable due to methane, gas lighter than air, without color and odor, and even one of the GHGs with the highest heat retention capacity. The typical biogas composition is about $60 \%$ methane, $35 \%$ of carbon dioxide and $5 \%$ of a mixture of hydrogen, nitrogen, ammonia, sulfuric acid, carbon monoxide, volatile amines and oxygen (AMARAL et al., 2006).

For the commercialization of carbon credits this gas can be directed to two purposes. The first is the burning, eliminating excess methane and turning it into carbon dioxide. Methane because it has a greater power of retention of heat is more harmful than the carbon dioxide, being a positive 
balance its burning. The second, and more sustainable, purpose would be to use as fuel for electric power generation. There are generators that work with gases from the biodigestion of organic waste, such as GE, jenbacher model (TSAI, LIN, 2009). Studies by Embrapa Pigs and Poultry indicate that, on average, for each 76 liters of liquid swine manure, $1 \mathrm{~m}^{3}$ of biogas is formed (AMARAL et al., 2006).

The waste after decomposition leaves the interior of the biodigestor in liquid form, the so-called biofertilizer. A compound rich in nutrients and organic material, with excellent use for fertilization. The application of this in the soil improves the biological, chemical and physical qualities of the same (BARICHELLO et al., 2015, VIVAN et al., 2010).

The biofertilizer can be used as organic fertilizer in organic agriculture, being applied alone or in mixtures with chemical fertilizers, increasing beyond plant nutrition, soil organic matter levels. In the present study, the presence of odor and the presence of odor in the soil were not observed (Sánchez et al., 2005).

In the case of swine manure, the composition of the biofertilizer has the following concentrations: from 0.5 to $4.0 \%$ of nitrogen; from 0.5 to $5.0 \%$ phosphorus; 0.5 to $3.0 \%$ potassium and about 90 to $95 \%$ water (AMARAL et al., 2006).

Thus, the biofertilizer is a byproduct originated in the process of biodigestion, which provides the maximum use of swine manures, optimizing the process of aggregation of value to the rural property.

\section{Conclusions and Recommendations}

There is great potential for commercial exploitation of carbon credits by small farms. Having as its main limiting factor its small reach, because alone, a single property can not afford the costs and certification bureaucracy for the sale of carbon credits. However, if organized in the form of cooperatives, these properties, in addition to having more commercial strength and technical support, can enter the carbon credit market much more easily and forcefully.

Organic farming systems and conservationists, in addition to generating a product with a higher added value in the market, also produce more carbon credits that can become an excellent source of alternative income. Conservation practices can also be certified by generating revenue for the smallholder.

For this type of practice to be established, it is necessary to intervene by the state, with the promotion, installation, training and training of cooperatives for this purpose. There is much potential, labor and will in smallholder areas.

\section{References}

[1] ABDO, Maria Teresa Vilela Nogueira; VALERI, Sérgio Valiengo; MARTINS, Antônio Lúcio Mello. Sistemas agroflorestais e agricultura familiar: uma parceria interessante. Revista tecnologia \& Inovação Agropecuária, p. 50-59, 2008. Disponível em: <https://www.researchgate.net/profile/Maria_Teresa_Abdo/publication/261706306_SISTEMAS_ 
[2] AGROFLORESTAIS_E_AGRICULTURA_FAMILIAR_UMA_PARCERIA_INTERESSANTE /links/00b7d535175fa47cd3000000.pdf>. Acesso em: 20 abr. 2017.

[3] AGUIAR, Teresinha de Jesus Alves De; MONTEIRO, Maria do Socorro Lira. Modelo agrícola e desenvolvimento sustentável: a ocupação do cerrado piauiense. Ambiente \& sociedade, v. 8, n. 2, p. 161-178, dez. 2005. Disponível em: $<$ http://www.scielo.br/scielo.php?script=sci_arttext\&pid=S1414753X2005000200009\&lng=pt\&nrm=iso\&tlng=pt>. Acesso em: 20 abr. 2017.

[4] ALBRECHT, Alain; KANDJI, Serigne T. Carbon sequestration in tropical agroforestry systems. Agriculture, Ecosystems \& Environment, v. 99, n. 1, p. 15-27, 2003. Disponível em: <http://www.sciencedirect.com/science/article/pii/S0167880903001385>. Acesso em: 14 abr. 2017.

[5] AMARAL, Armando Lopes Do et al.Boas Práticas de Produção de Suínos. . Brasilia: [s.n.], 2006. Disponível em: <http://www.cnpsa.embrapa.br/sgc/sgc_publicacoes/publicacao_k5u59t7m.pdf>. Acesso em: 22 maio 2017.

[6] ARATO, Helga Dias; MARTINS, Sebastião Venâncio; FERRARI, Silvia Helena de Souza. Produção e decomposição de serapilheira em um sistema agroflorestal implantado para recuperação de área degradada em Viçosa-MG. Revista Árvore, v. 27, n. 5, p. 715-721, out. 2003. Disponível em:

$<$ http://www.scielo.br/scielo.php?script=sci_arttext\&pid=S010067622003000500014\&lng=pt\&nrm=iso\&tlng=pt>. Acesso em: 20 abr. 2017.

[7] BARICHELLO, Rodrigo et al. O USO DE BIODIGESTORES EM PEQUENAS E MÉDIAS PROPRIEDADES RURAIS COM ÊNFASE NA AGREGAÇÃO DE VALOR: UM ESTUDO DE CASO NA REGIÃO NOROESTE DO RIO GRANDE DO SUL. Revista em Agronegócio e Meio Ambiente, v. 8, n. 2, p. 333-355, 2015. Disponível em: <http://dx.doi.org/10.17765/2176-9168.2015v8n2p333-355>. Acesso em: 13 abr. 2017.

[8] CALDEIRA, Marcos Vinicius Winckler et al. Quantificação de serapilheira e de nutrientes em uma Floresta Ombrófila Densa. Semina: Ciências Agrárias, v. 29, n. 1, p. 53, 30 ago. 2008. Disponível em: <http://www.uel.br/revistas/uel/index.php/semagrarias/article/view/2853>. Acesso em: 20 abr. 2017.

[9] CAMPANHOLA, Clayton; VALARINI, Pedro José. Cadernos de ciência \&amp; tecnologia. [S.1: s.n.], 2001. v. 18. Disponível em: <http://seer.sct.embrapa.br/index.php/cct/article/view/8851>. Acesso em: 20 abr. 2017.

[10] CAPORAL, Francisco Roberto; COSTABEBER, José Antônio. Agroecologia: Enfoque científico e estratégico. Agroecologia e Desenvimento Rural Sustentavel, v. 3, n. 2, 2002. Disponível em: <http://www.pvnocampo.com.br/agroecologia/agroecologia.pdf>. Acesso em: 19 abr. 2017.

[11] CARVALHO, João Luis Nunes et al. Potencial de sequestro de carbono em diferentes biomas do Brasil. Revista Brasileira de Ciência do Solo, v. 34, n. 2, p. 277-290, abr. 2010. Disponível em: $<$ http://www.scielo.br/scielo.php?script=sci_arttext\&pid=S010006832010000200001\&lng=pt\&nrm=iso\&tlng=pt >. Acesso em: 13 abr. 2017.

[12] CASTRO FILHO, C.; MUZILLI, O.; PODANOSCHI, A. L. Estabilidade dos agregados e sua relação com o teor de carbono orgânico num latossolo roxo distrófico, em função de sistemas de plantio, rotações de culturas e métodos de preparo das amostras. Revista Brasileira de Ciência do Solo, v. 22, n. 3, p. 527-538, set. 1998. Disponível em: <http://www.scielo.br/scielo.php?script=sci_arttext\&pid=S010006831998000300019\&lng=pt\&nrm=iso\&tlng=en>. Acesso em: 19 abr. 2017.

[13] CONEJERO, Marco Antonio. Marketing de créditos de carbono: um estudo exploratório. 2006. 243 f. Universidade de São Paulo, 2006.

[14] Crédito Carbono Futuros Preços - Investing.com. Disponível em: <https://br.investing.com/commodities/carbon-emissions>. Acesso em: 14 abr. 2017. 
[15] FERNANDES, Tarcísio José Gualberto et al. Quantificação do carbono estocado na parte aérea e raízes de Hevea sp., aos 12 anos de idade, na Zona da Mata Mineira. Revista Árvore, v. 31, n. 4, p. 657-665, ago. 2007. Disponível em:

$<$ http://www.scielo.br/scielo.php?script=sci_arttext\&pid=S0100-

67622007000400010\&lng=pt\&nrm=iso\&tlng=pt $>$. Acesso em: 13 abr. 2017.

[16] FOLEY, Jonathan A. et al. Global Consequences of Land Use. Science, v. 309, n. 5734, p. 570574, 2005. Disponível em: <http://science.sciencemag.org/content/309/5734/570.full>. Acesso em: 14 abr. 2017.

[17] GOMES, Ivair. Sustentabilidade social e ambiental na agricultura familiar. Revista de Biologia e Ciências da Terra, v. 5, n. 1, p. 1-17, 2004. Disponível em:

<http://joaootavio.com.br/bioterra/workspace/uploads/artigos/agriculturafamiliar5181dc7eaf45b.pdf>. Acesso em: 20 abr. 2017.

[18] GYENGE, J.E. et al. Silvopastoral systems in Northwestern Patagonia II: water balance and water potential in a stand of Pinus ponderosa and native grassland. Agroforestry Systems, v. 55, n. 1, p. 47-55, 2002. Disponível em: <http://link.springer.com/article/10.1023/A:1020269432671〉.

[19] IPCC. Summary for Policymakers. [S.l: s.n.], 2014.

[20] JACOBI, Pedro. Educação ambiental, cidadania e sustentabilidade. Cadernos de Pesquisa, n. 118, p. 189-206, mar. 2003. Disponível em:

$<$ http://www.scielo.br/scielo.php?script=sci_arttext\&pid=S0100-

$15742003000100008 \& \operatorname{lng}=$ pt\&nrm=iso\&tlng=pt>. Acesso em: 19 abr. 2017.

[21] LOPES, Alfredo Scheid. Solos sob "cerrado": características, propriedades e manejo. 2. ed. Piracicaba: Esalq - Escola Superior de Agricultura de Lavras, 1984.

[22] MACIEL, Carolina Veloso et al. Crédito De Carbono: Comercialização E Contabilização a Partir De Projetos De Mecanismo De Desenvolvimento Limpo. Revista de Informação Contábil, v. 3, n. 1, p. 89-112, 2009.

[23] PINHO, D.B. O pensamento cooperativo e o cooperativismo brasileiro. Manual de cooperativismo. São Paulo: Cooperativa Mista de Cultura e Trabalho Ltda., 1982. Disponível em: $<$ http://www.sidalc.net/cgi$\mathrm{bin} / \mathrm{wxis}$.exe/?IsisScript=AGB $\cdot$ xis \&method=post $\&$ formato $=2 \&$ cantidad $=1 \&$ expresion $=\mathrm{mfn}=077$ 378>. Acesso em: 20 abr. 2017.

[24] RATTER, J. The Brazilian Cerrado Vegetation and Threats to its Biodiversity. Annals of Botany, v. 80, n. 3, p. 223-230, set. 1997. Disponível em:

<https://academic.oup.com/aob/article-lookup/doi/10.1006/anbo.1997.0469>. Acesso em: 20 abr. 2017.

[25] ROQUE RODIGHERI, Honorino; ROBERTO GRAÇA, Luiz; APARECIDA DE LIMA, Magda. Indicadores de Custos, Produtividade, Renda e Créditos de Carbono de Plantios de Eucaliptos e Pínus em Pequenas Propriedades Rurais *. Colombo, PR: [s.n.], 2005. Disponível em: <https://ainfo.cnptia.embrapa.br/digital/bitstream/CNPF-2009-09/39413/1/com_tec136.pdf>. Acesso em: 13 abr. 2017.

[26] ROSCOE, Renato; MERCANTE, Fabio Martins; SLATON, Julio Cesar. Dinâmica da matéria orgânica do Solo. Dinâmica da matéria orgânica do solo em sistemas conservacionistas: modelagem matemática e métodos auxiliares. Dourados: EMBRAPA, 2006. p. 17-42.

[27] SÁNCHEZ, E. et al. Effect of organic loading rate on the stability, operational parameters and performance of a secondary upflow anaerobic sludge bed reactor treating piggery waste. Bioresource Technology, v. 96, n. 3, p. 335-344, 2005. Disponível em: <http://www.sciencedirect.com/science/article/pii/S0960852404001440>. Acesso em: 22 maio 2017.

[28] SANTANA, Claudio Alexandre de Aquino; LIMA, Cátia Cilene Doneles De; MAGALHÃES, Luís Mauro Sampaio. Estrutura horizontal e composição florística de três fragmentos secundários na cidade do Rio de Janeiro. Acta Scientiarum. Biological Sciences, v. 26, n. 4, p. 443-451, 1 abr. 
2004. Disponível em: <http://periodicos.uem.br/ojs/index.php/ActaSciBiolSci/article/view/1525>. Acesso em: 20 abr. 2017.

[29] SHNEIDER, Sérgio. Teoria social, agricultura familiar e pluriatividade. Revista Brasileira de Ciências Sociais, v. 18, n. 51, p. 99-121, 2003. Disponível em:

<http://www.scielo.br/pdf/rbcsoc/v18n51/15988>. Acesso em: 20 abr. 2017.

[30] SOUZA COSTA, Josimar et al. Social Technology as a Sustainable Public Policy: The Mandalla Project in Ceará. Journal of technology management \& innovation, v. 8, p. 31-32, 2013. Disponível em:

<http://www.scielo.cl/scielo.php?script=sci_arttext\&pid=S0718$27242013000300016 \& \operatorname{lng}=e n \& n r m=i s o \& t \operatorname{lng}=e n>$. Acesso em: 19 abr. 2017.

[31] TOLENTINO, Marlo; ROCHA-FILHO, Romeu C. A química no efeito estufa. . [S.l: s.n.], 1998. Disponível em: <http://qnesc.sbq.org.br/online/qnesc08/quimsoc.pdf>. Acesso em: 13 abr. 2017.

[32] TSAI, Wen-Tien; LIN, Che-I. Overview analysis of bioenergy from livestock manure management in Taiwan. Renewable and Sustainable Energy Reviews, v. 13, n. 9, p. 2682-2688, dez. 2009. Disponível em: <http://linkinghub.elsevier.com/retrieve/pii/S1364032109001130>. Acesso em: 22 maio 2017.

[33] VEIGA, José Eli Da. Cadernos de ciência \&amp; tecnologia. [S.l: s.n.], 1996. v. 13. Disponível em: <https://seer.sct.embrapa.br/index.php/cct/article/view/9009>. Acesso em: 20 abr. 2017.

[34] VIVAN, Marcelo et al. Eficiência da interação biodigestor e lagoas de estabilização na remoção de poluentes em dejetos de suínos. Revista Brasileira de Engenharia Agrícola e Ambiental, v. 14, n. 3, p. 320-325, mar. 2010. Disponível em:

$<$ http://www.scielo.br/scielo.php?script=sci_arttext\&pid=S1415$43662010000300013 \& \operatorname{lng}=p t \& t \operatorname{lng}=\mathrm{pt}>$. Acesso em: 22 maio 2017.

[35] WALTER, Bruno Machado Teles. Fitofisionomias do bioma Cerrado : síntese terminológica e relações florísticas . 2006. 389 f. Universudade de Brasilia, 2006.

[36] WINCK, Bruna Raquel et al. Carbono e nitrog??nio nas fra????es granulom??tricas da mat??ria org??nica do solo, em sistemas de culturas sob plantio direto. Revista Brasileira de Ciencia do Solo, v. 38, n. 3, p. 980-989, 2014.

[37] WOHLENBERG, E. V. et al. Dinâmica da agregação de um solo franco-arenoso em cinco sistemas de culturas em rotação e em sucessão. Revista Brasileira de Ciência do Solo, v. 28, n. 5, p. 891900, out. 2004. Disponível em: <http://www.scielo.br/scielo.php?script=sci_arttext\&pid=S010006832004000500011\&lng=pt\&nrm=iso\&tlng=pt>. Acesso em: 19 abr. 2017.

[38] XAVIER, De Cristiane A N; JÚNIOR, Lucas De Jorge. PARÂMETROS DE DIMENSIONAMENTO PARA BIODIGESTORES BATELADA OPERADOS COM DEJETOS DE VACAS LEITEIRAS COM E SEM USO DE INÓCULO. Engenharia Agrícola, v. 30, n. 2, p. 212-223, 2010. Disponível em: <http://www.scielo.br/pdf/eagri/v30n2/v30n2a03>. Acesso em: 22 maio 2017.

[39] YU, Chang Man. Seqüestro florestal de carbono no Brasil - Dimensões políticas socioeconômicas e ecológicas 1. 2004. 1-23 f. Universidade Federal do Paraná, 2004.

\footnotetext{
*Corresponding author.

E-mail address: jadsonbelem@ gmail.com
} 